\title{
Intentional Leadership Planning and Development: The Collective Responsibility to Educate More Social Work Leaders
}

\author{
Christa C. Gilliam \\ Marquis A. Chandler \\ Huda A. Al-Hajjaj \\ Angelica N. Mooney \\ Halaevalu F. O. Vakalahi
}

\begin{abstract}
Social workers have the capacity and skills to assume leadership positions in social service agencies. Social work educational institutions must continue to prepare and encourage graduates to seek leadership roles in social service agencies. Social work curriculum and post-graduate professional development are significant avenues to ensure social workers will be excellent choices as organizational leaders and administrators. This article offers a review of the literature to identify gaps and ways to cultivate leaders through intentional recruitment and continuous training of social workers in human service leadership and administration.
\end{abstract}

Keywords: Succession planning; human services; social work; leadership; administration

As leaders and administrators in public social service agencies begin to reach the age of retirement, an urgent need to develop and implement succession plans for social work leadership is emerging. A 2003 study by Birdfell and Muzzio affirmed this need, pointing to "... a looming crisis in nonprofit management, with many nonprofit leaders on the verge of retirement and few potential leaders poised to take over" (Nesoff, 2007, p. 283). Due to the aging population, demand for management positions in social and community service agencies is expected to rise about 21\% from 2012 to 2022, an increase higher than the average for all other occupations (U.S. Bureau of Labor Statistics, 2014). Moreover, according to Frick (2011), succession planning and strategic leadership development is insufficient to meet current demands in state and nonprofit organizations. Thus, efforts to recruit and develop leaders must be intentional. Due to the lack of leadership planning, agencies find themselves with unintentional interims rather than a permanent leader (Frick, 2011). Searches, recruitment, training, and retention of multiple interims can cost at least ten times the base salary of a permanent executive. Without some intentional leadership planning and development, this process can become an ongoing cycle and financial burden on the agency's time and resources (Frick, 2011).

Succession planning as the means by which to identify, recruit and train high potential employees to assume leadership roles is essential to the organization's success (Wilkerson, 2007). Organizational performance and change in leadership often leads to compromised organizational performance (Leland, Carman \& Swartz, 2012). Succession planning is a form of stewardship necessary to influence and change policy. Good governance depends upon developing the strategic leadership competencies and values of leaders (Wilkins, 2014). Yet in a study of 110 nonprofit administrators, Leland and colleagues (2012)

Christa C. Gilliam, PhD, MSW is Assistant Professor, Department of Social Work, West Chester University of Pennsylvania, West Chester, PA, 19383. Marquis A. Chandler, MSW, Huda Al-Hajjaj, MSW, and Angelica N. Mooney, MSW, are a PhD Candidates, School of Social Work, Morgan State University, Baltimore, MD, 21251. Halaevalu F. O. Vakalahi, PhD, MSW, MEd is the Associate Dean and Professor, School of Social Work, Morgan State University, Baltimore, MD, 21251. 
reported that a majority of the participants $(75 \%)$ did not embrace succession planning as one of their central tasks as a leader.

Reid (2011) further indicated that the continuous crises in management exist as a result of leaders being uninterested in taking on leadership tasks, the assumption that succession planning is beyond a leader's scope of work, confusion about how the succession task should be framed, and the lack of information about how to carry out such planning. However, leadership planning and development is a collective responsibility. Agencies need to address the issue of succession planning, and schools of social work need to prepare and equip graduates to take on leadership roles. De-emphasizing macro-level administration and leadership training in schools of social work in favor of direct service and clinical training is well-documented (de Saxe Zerden, Sheely, \& Despard, 2016; Ezell, Chernesky \& Healy, 2004; Rank \& Hutchison, 2000). As a result, an increasing number of human service agencies are being led by executives with degrees from disciplines other than social work (Packard, 2004; Patti, 2003). Although critical thinking and decisionmaking are core competencies in social work curricula and professional development, social workers interested in leadership and administrative positions are often in competition with those trained in nonprofit and law degree programs (Ezell et al., 2004).

The terms leadership, management, and administration are used interchangeably throughout the literature. However, there are important distinctions. As such, "The overriding function of management is to provide order and consistency to organizations, whereas the primary function of leadership is to produce change and movement" (Northouse, 2010, p.10). Furthermore, administration is responsible for policy and decision-making, whereas the manager or leader is responsible for the implementation of policy within the limits set by the administration (Kettner, 2002). This article offers a critical analysis of existing literature pertaining to the role schools of social work play in preparing social work students to assume leadership positions in human services agencies. Although the literature is sparse, available information affirms the significance of preparing trained social workers as viable candidates for leadership, management, and administrative positions in social service agencies.

\section{Review of Relevant Literature}

\section{Status of Social Work Leadership}

While social work leadership is not a new area, it remains an emerging research topic, as there is a large gap in the literature in terms of evidence-based practices. The existing literature is limited in relation to studies that examine the perceptions of social work executives, academics, practitioners, and students regarding leadership. In a study of 150 social work leaders by Rank and Hutchison (2000), 77\% of participants indicated that a social work leader is unique compared to leaders from other professions. For instance, participants believed their social work background contributed to their role as a leader. Themes identified as contributing to their leadership role included a commitment to the NASW Code of Ethics, a systemic perspective, altruism, and concern about the public image of the profession. These themes not only represent the strengths of social work 
leadership, but may also generate challenges when social workers are considered for traditional leadership roles in human service agencies.

The development of social work leaders is a collective responsibility that includes schools of social work, social service agencies, and professional organizations. Currently, most social work schools across the country fail to offer a focus on social work administration. Of the 710 baccalaureate and master's level programs accredited by the Council of Social Work Education, only 37 offer a concentration in management and planning (CSWE, 2015). Day (2011) found that many managers of human service organizations lack advanced degrees and thus the additional knowledge and skills needed for effective leadership and administration. The limited number of management-oriented degrees presents a challenge in meeting the demand for leaders prepared to address today's challenging social and economic environments.

The need for investment in training social workers for leadership and management positions has become a significant issue for several reasons. First, the gerontologic shift in the U.S. population has resulted in a rising need for social workers. Second, the inherent foundation of social work in leadership values such as advocacy, social and economic justice, and competency-based practice leads to a strong base for training leaders. The fields of business and public administration have successfully trained administrators for a variety of organizations. However, the emphasis in social work on multidimensional systems and the commitment to a distinctive code of ethics offers a unique framework for training future leaders and administrators of social service agencies (Nesoff, 2007).

The literature on social work leadership is limited. Available information suggests that in general, social workers are effective leaders. For example, Day (2011) observed that leaders of medical centers rated social work leaders higher on measures of management skills than the social workers rated themselves. While respected by their medically trained colleagues for their managerial competencies, it is clear that social work leaders may experience self-doubt and personal insecurities about their ability to lead, manage, and administer a social service agency. Similarly, Collins-Camargo, Chuang, McBeath, and Bunger (2014) found private child welfare agencies were better equipped than public agencies to meet the needs of their clientele due to excellent management performance and strategies.

\section{Preparing Social Work Leaders}

Schools of social work have a significant role in partnership with professional organizations such as the National Association of Social Workers and the Council on Social Work Education to educate and prepare competent leaders to lead social service agencies (Fisher, 2009). Social work graduates who are placed in leadership positions without sufficient preparation often struggle to meet the standards of the positions. As a result, this lack of experience and mentorship can contribute to social workers being passed up for leadership and management positions in social service agencies (Bliss, Pecukonis, \& Snyder-Vogel, 2015). There is a national shortage of social-work-trained practitioners and an even larger shortage of social-work-trained leaders who are well-prepared to manage and lead social service agencies (NASW, 2011; U.S. Bureau of Labor Statistics, 2015). A 
reason for this shortage is the small number of schools of social work training graduates specifically as leaders and administrators of social service agencies. In addition to increasing leadership and administration concentrations, there is a need for universities to offer more comprehensive, innovative, and interdisciplinary curricula to their social work students. Emphasizing social work's value of lifelong learning, social work curricula must also include components of post-graduate/continuing education and professional development specifically focused on leadership and administration of social service agencies (Fisher, 2009; Wuenschel, 2006).

In training social work leaders, many relevant models of leadership are available for consideration by schools of social work. A number of studies have explored the various models of leadership used in social work and social service agencies. For instance, Williams-Gray (2014) examined an innovative approach to preparing professional social workers for real-world nonprofit leadership roles. Results indicated that virtual asynchronous classroom experiences were effective for teaching MSW students and that students who are prepared in generalist practice and social work administration are overlooked for nonprofit leadership (Williams-Gray, 2014). Furthermore, Bliss et al. (2014) support the Principled Leadership Development Model for addressing the gap in social work leadership. This model can create adaptable leadership development initiatives for social workers in their professional careers. This model introduced six integrated components: a) underpinning ethical principles, b) core leadership competencies, c) domain-specific leadership competencies, d) integrative practice opportunities and mentoring support, e) ongoing self-reflection and continued growth, and f) evaluation (Bliss et al., 2014). These components can be applied to leadership development among individuals pursuing a Master's of Social Work degree and/or continuing education and professional development.

Several studies have explored social work leadership from an international perspective. McNabb and Webster (2010) compared the leadership approaches used in health policy initiatives in New Zealand and the United States, finding that social workers played the role of the emergent leader, supporting their ability to contribute to leadership positions effectively. In Canada, Butcher (2013) studied 15 female community leaders in Waterloo regarding their journey to leadership. Themes that emerged from the study included responding to injustice, making a lasting difference, and the importance of fostering independence and developing social consciousness at an early age. The impact of leadership in the community, sustaining factors of family and peer support, and the role of formal and informal recognition were also identified. Rejection of traditional models of leadership and redefining community leadership were areas identified for further exploration relative to developing female leaders. The Butcher study also points out that women comprise the greatest proportion of social workers in the United States. The study concludes that women are in a position to become effective leaders of human services organizations.

The Urban Leadership Program (ULP) was developed in 1998 by Simmons College in Massachusetts to address the leadership needs of social service organizations in urban communities (Mittell, 2012). This certificate program provides students with an in-depth opportunity to develop their leadership abilities in order to assume social service leadership 
roles in urban areas. In addition to the required MSW courses, students in the ULP are required to complete two leadership skills courses and four skills-based mini-courses which provide them with the theoretical and practical foundation for building leadership skills. The program is designed to teach students how to comprehensively assess an organization and the obstacles that impede the delivery of effective, cost-efficient services. Field instruction provides hands-on leadership practice with supervision by community leaders of urban agencies.

Faculty members in schools of social work play a crucial role in not only teaching the curriculum, but also modeling leadership values and practices to students. The commitment of faculty to educate social work leaders is important; their own experiences with academic and non-academic leadership contribute to their utility. Call, Owens, and Vincent (2013) found that faculty believed academic leaders demonstrated transformational leadership qualities, such as a collaborative style that encouraged shared governance, ethical practices, inspirational presence, mentoring activities, relationship-enhancing communication skills, and visionary perspectives. These qualities are consistent with the core values of social work. Drawing upon these experiences with strong campus leaders, faculty can develop social work leadership curricula, and nurture graduates who exhibit leadership traits, such as professionalism, advocacy, and commitment to social justice.

\section{Leadership Challenges}

Among social workers, leadership challenges are multi-faceted, multi-dimensional, and inclusive of individual experiences and organizational challenges. Management and supervisory positions in social service agencies are commonly filled by non-social-work professionals. This poses a challenge as the decisions of social workers are being evaluated by leaders with little insight into the profession and the populations served (NASW, 2011). Non-social-work staff may not share the same professional values and ethics, which can present a barrier to understanding the holistic approach to social work practice. Furthermore, social workers seek to enhance the capacity of people to address their own needs, as well as promote the responsiveness of organizations, communities, and other social institutions to the problems and needs of individuals (NASW, 2011). Such endeavors may not be at the forefront of a non-social-work leader's agenda. As suggested by Wuenschel (2006), leadership in social work academia needs to develop a theoretical perspective for leadership and management that is unique to social service agencies.

A major barrier to advancement in leadership within a social service agency is the high level of burnout among supervisory and case management social workers. Such burnout could be contributing to the low numbers of social workers available for leadership and administrative positions (Webb \& Carpenter, 2012; Williams, Nichols, Kirk, \& Wilson, 2011). Wells (2006) also comments that, due to burnout resulting from individual circumstances or a non-supportive organizational system, social workers are not retained in positions long enough to acquire the necessary skills for promotions. The high workforce turnover rates resulting from the intensity of a social worker's daily life, the shortage of social-work-educated professionals, and the associated negative impacts on service users and agencies have been long-standing concerns in many developed countries, especially the United States (Webb \& Carpenter, 2012). Nonetheless, some workforce turnover is 
both natural and inevitable, especially when considering that not all who enter the social work profession should or will remain in practice, and those who leave do so for a variety of reasons (Webb \& Carpenter, 2012).

Moreover, the life of a modern-day social work leader clearly is not easy given the social and economic crises experienced by individuals, families, and communities in the past several years. Inside social service organizations, social work leaders must lead and motivate a diversified group of people, work across organizational boundaries, improve efficiency, and achieve growth. Externally, these social work leaders face a complex and globalized environment, and yet must manage the requirements of government and keep up with competitors. Within this global environment, there are many cultural considerations that social work leaders must grapple with in order to be effective. Today's social work leaders must work across cultural boundaries with others who likely have different ways of working (Gentry, Eckert, Stawiski \& Zhao, 2014). Overall, the literature suggests several major gaps, including: a) the need for specific training in leadership, management, and administration for social workers and b) the lack of evidence-based best practices for social work leadership.

\section{Analysis and Discussion}

Social workers serve in leadership roles across different environments, but not in sufficient numbers, and not always as the first choice for leadership positions. The reasons for the low numbers of social work leaders are complex and multi-dimensional. A comprehensive training approach that includes personal and professional interests and confidence in one's preparation and competence is imperative. Social workers can become effective leaders in social service agencies if they are fully prepared through social work curriculum and post-graduate professional development that focuses on leadership and administration. The most effective social work leaders receive leadership training and education that prepares them to provide effective services to underserved populations. Available information attests to the qualifications and capacity of social workers as leaders and administrators of social service agencies. Social workers with the appropriate background in terms of education and work experience in macro-level practice and administration are excellent candidates for leadership positions in social service agencies. Schools of social work are in prominent positions to educate, train, and graduate wellprepared social work leaders.

Additionally, a need for more comprehensive, interdisciplinary, and cross-cultural leadership training for social work leaders is affirmed. Social work leadership curriculum can provide opportunities to develop transformational leadership qualities, shared governance, communication skills, and visionary perspective. For example, social workers can develop the leadership competencies recommended by the Network for Social Work Managers and adopted by the Council on Social Work Education which include an emphasis on the business side of leading an agency, including knowledge and skills in budgeting, fundraising, marketing, and governance (Wimpfheimer, 2004).

The field education component of social work also provides a real-world setting for training social work leaders. For instance, field education can offer opportunities to 
develop administrative skills such as organizing, budgeting, communication, group work, research and evaluation, and other management skills. Schools of social work can redefine community leadership to be relevant for the $21^{\text {st }}$ century in diverse contexts including both rural and urban settings.

Overall, social workers have demonstrated their capacity to lead organizations. An investment of resources in training additional social work leaders to replace retiring leaders is urgently needed. An intentionally well-developed succession plan will sustain continuity and increase the quality of services provided. Analysis of the literature generated several significant implications that may contribute to future understanding and initiatives that promote the education, training, and retention of social work leaders in social service agencies.

First, social work scholars must increase the knowledge base on theories and best practices to support social workers in leadership positions in social service agencies. Such research endeavors can also identify areas where further expertise is needed. Second, intentional recruitment and retention of social work leaders from schools of social work and within social service agencies is imperative. Incentives such as monetary rewards and programs that create opportunities for retention of top talent, promotion, and growth need to be instituted in social service agencies.

Third, human services agencies can create the conditions for successful development and retention of social work leaders by creating a supportive organizational culture and providing training opportunities that align with the agency's current needs and future directions for leadership (Gothard \& Austin, 2013). Policies that support opportunities and allocate funding for social work leadership development would increase the likelihood of more social work practitioners pursuing leadership careers. Recruitment strategies within agencies may include collaborating with schools of social work to identify candidates and instituting internal recruitment and grooming of practitioners with a knack for leadership. Within agencies, mentoring strategies may include one-on-one coaching, group mentoring and professional development opportunities including partnering with local schools of social work on research and publication (Germak, 2012).

Fourth, schools of social work must reconsider the current dichotomizing of social work as micro or macro practice, instead of social work as inclusive of both micro and macro practice. The link between micro and macro level practice should be sustained in the development of social work leaders. Schools of social work must also increase the number of concentrations offered in social work leadership and administration to increase the number of students prepared to enter the workforce in leadership positions with social service agencies. These concentrations must also be culturally and linguistically relevant for leading an increasingly diverse workforce. The multidimensional systems perspective, code of ethics, a focus on leading social change efforts, and advocating for social and economic justice for all, provides a unique framework and promising opportunities to develop well-rounded leaders.

Finally, advancing the conversation requires a cultural shift in leadership and administration perspectives, theories, and best practices. With the diversity in the workforce, particularly in terms of the growing numbers of women of color interested in 
leadership positions (Sanchez-Hucles \& Davis, 2010), there is a need to diversify the pool of leadership and administration through breaking systemic barriers, extensive coaching, and proper education and professional development. In all of these endeavors to prepare culturally and linguistically competent leaders, schools of social work have a major role given their foundation in values, ethics, advocacy, promotion of equity, respect for diversity, and social justice.

\section{References}

Bliss, D., Pecukonis, E., \& Snyder-Vogel, M. (2014). Principled leadership development model for aspiring social work managers and administrators: Development and application. Human Service Organizations: Management, Leadership \& Governance, 38(1), 5-15. doi:http://dx.doi.org/10.1080/03643107.2013.853008

Butcher, L. A. (2013). The road less travelled: Women's journeys to community leadership in the Waterloo Region (Master's thesis). Wilfrid Laurier University, Ontario, Canada. Retrieved from http://scholars.wlu.ca/etd/1624/

Call, C. R., Owens, L. W., \& Vincent, N. J. (2013). Leadership in social work education: Sustaining collaboration and mission. Advances in Social Work, 14(2), 594-612.

Collins-Camargo, C., Chuang, E., McBeath, B., \& Bunger, A. C. (2014). Private child welfare agency managers' perceptions of the effectiveness of different performance management strategies. Children and Youth Services Review, 38, 133-141. doi:http://dx.doi.org/10.1016/j.childyouth.2014.01.019

Council on Social Work Education. (2015). Commission on Accreditation: 2008 statistics on social work education in the United States. Retrieved from http://www.cswe.org/CentersInitiatives/DataStatistics/ProgramData/52539/44889.asp $\underline{\mathrm{x}}$

Day, K. (2011). Assessing the leadership and management skills of senior VA social work leaders by internal stakeholders (Doctoral dissertation). The Catholic University of America, Washington, D.C. Retrieved from http://aladinrc.wrlc.org/handle/1961/9305

de Saxe Zerden, L., Sheely, A., \& Despard, M. R. (2016). Debunking macro myths: Findings from recent graduates about jobs, salaries, and skills. Social Work Education, 35(7), 752-766. doi:http://dx.doi.org/10.1080/02615479.2016.1188915

Ezell, M., Chernesky, R. H., \& Healy, L. M. (2004). The learning climate for administration students. Administration in Social Work, 28(1), 57-76. doi:http://dx.doi.org/10.1300/J147v28n01_05

Fisher, E. A. (2009). Motivation and leadership in social work management: A review of theories and related studies. Administration in Social Work, 33(4), 347-367. doi:http://dx.doi.org/10.1080/03643100902769160

Frick, J. (2011). Succession planning and leadership transition. Communities in Schools. Retrieved from http://www.communitiesinschools.org/media/uploads/attachments/ Judy Fricks Leadership Transition Report.pdf 
Gentry, W., Eckert, R., Stawiski, S., \& Zhao, S. (2014). The challenges leaders face around the world: More similar than different. Retrieved from http://www.ccl.org/Leadership/pdf/research/ChallengesLeadersFace.pdf

Germak, A.J. (2012). Building leadership and management capacity in the human service sector through training and professional development. Huamin Research Center, School of Social Work, Rutgers University. Retrieved from http://socialwork.rutgers.edu/centersandprograms/Huamin.aspx

Gothard, S., \& Austin, M. J. (2013). Leadership succession planning: Implications for nonprofit human service organizations. Administration in Social Work, 37(3), 272285. doi:http://dx.doi.org/10.1080/03643107.2012.684741

Kettner, P. M. (2002). Achieving excellence in the management of human services organizations. Boston, MA: Allyn \& Bacon.

Leland, S. M., Carman, J. G., \& Swartz, N. J. (2012). Understanding managerial succession planning at the local level: A study of the opportunities and challenges facing cities and counties. National Civic Review, 101(2), 44-50. doi:http://dx.doi.org/10.1002/ncr.21076

McNabb, D., \& Webster, M. (2010). Qualities and practices of professional social work leadership in an interdisciplinary mental health service: An action learning approach. Action Learning: Research and Practice, 7(1), 41-57. doi:http://dx.doi.org/10.1080/14767330903576846

Mittell, E. S. (2012, October). Promoting leadership learning in clinical field education: The Urban Leadership Program at Simmons School of Social Work. Field Educator. Retrieved from http://www2.simmons.edu/ssw/fe/i/Mittell.pdf

National Association of Social Workers. (2011). Code of ethics of the National Association of Social Workers. Retrieved from http://www.utexas.edu/ssw/dl/files/academic-programs/other/nasw-code-of-ethics.pdf

Nesoff, I. (2007). The importance of revitalizing management education for social workers. Social Work, 52(3), 283-285. doi:http://dx.doi.org/10.1093/sw/52.3.283

Northouse, P. G. (2010). Leadership: Theory and practice (5th ed.). Thousand Oaks, CA: Sage.

Packard, T. (2004). Issues in designing and adapting an administration concentration. Administration in Social Work, 2(1), 5-19. doi:http://dx.doi.org/10.1300/J147v28n01_02

Patti, R. J. (2003). Reflections on the state of management in social work. Administration in Social Work, 27(2), 1-11. doi:http://dx.doi.org/10.1300/J147v27n02_01

Rank, M. G., \& Hutchison, W. S. (2000). An analysis of leadership within the social work profession. Journal of Social Work Education, 36(3), 487-502. 
Reid, M. (2011). Applying succession management benefits for leadership continuity. Journal of Business \& Economics Research (JBER), 3(6), 35-44. doi:http://dx.doi.org/10.19030/jber.v3i6.2782

Sanchez-Hucles, J. V., \& Davis, D. D. (2010). Women and women of color in leadership: Complexity, identity, and intersectionality. American Psychologist, 65(3), 171-181. doi:http://dx.doi.org/10.1037/a0017459

U.S. Department of Labor, Bureau of Labor Statistics. (2015). Occupational outlook handbook 2014-2015 Edition: Social and Community Service Managers. Retrieved from http://www.bls.gov/ooh/management/social-and-community-servicemanagers.htm

Webb, C., \& Carpenter, J. (2012). What can be done to promote the retention of social workers? A systematic review of intervention. British Journal of Social Work, 42, 1235-1255. doi:http://dx.doi.org/10.1093/bjsw/bcr144

Wells, R. (2006). Managing child welfare agencies: What do we know about what works? Children and Youth Services Review, 28(10), 1181-1194. doi:http://dx.doi.org/10.1016/j.childyouth.2005.11.009

Wilkerson, B. (2007). Effective succession planning in the public sector. Retrieved from Wyatt Watson Worldwide website: http://www.4cleanair.org/Chicago/ EffectiveSuccessionPlanningforPublic.pdf

Wilkins, J. (2014). Stewardship of public service renewal and reform. International Journal of Leadership in Public Service, 10(4), 188-199. doi:http://dx.doi.org/10.1108/IJLPS-07-2014-0009

Williams, S. E., Nichols, Q., Kirk, A., \& Wilson, T. (2011). A recent look at the factors influencing workforce retention in public child welfare. Children and Youth Services Review, 33(1), 157-160. doi:http://dx.doi.org/10.1016/j.childyouth.2010.08.028

Williams-Gray, B. (2014). Preparation for social service leadership: Field work and virtual organizations that promote critical thinking in administration practice. Journal of Teaching in Social Work, 34(2), 113-128. doi:http://dx.doi.org/10.1080/08841233.2014.892050

Wimpfheimer, S. (2004). Leadership and management competencies defined by practicing social work managers: An overview of standards developed by the National Network for Social Work Managers. Administration in Social Work, 28(1), 45-56. doi:http://dx.doi.org/10.1300/J147v28n01_04

Wuenschel, P. C. (2006). The diminishing role of social work administrators in social service agencies: Issues for consideration. Administration in Social Work, 30(4), 518. doi:http://dx.doi.org/10.1300/J147v30n04_02

\section{Author note:}

Address correspondence to: Christa C. Gilliam, PhD, MSW, Department of Social Work, West Chester University of Pennsylvania, 700 S. High Street, West Chester, PA, 19383, 610-436-1000, cgilliam@wcupa.edu 